TEME, г. XLIV, бр. 1, јануар - март 2020, стр. 285-300

Оригинални научни рад $\quad$ https://doi.org/10.22190/TEME180614021R

Примљено: 14. 6. 2018.

UDK 004.6:519.6

Ревидирана верзија: 30. 12. 2018.

Одобрено за штампу: 20. 2. 2020.

\title{
AN INTEGRATED DEA/AHP METHODOLOGY FOR DETERMINING THE CRITERIA IMPORTANCE IN THE PROCESS OF BUSINESS-FRIENDLY CERTIFICATION AT THE LOCAL LEVEL
}

\author{
Milan Ranđelović ${ }^{1 *}$, Gordana Savić ${ }^{2}$ \\ Boban Stojanović ${ }^{3}$, Dragan Ranđelović \\ ${ }^{1}$ Science Technology Park Niš, Niš, Serbia \\ ${ }^{2}$ University of Belgrade, Faculty of Organizational Sciences, Belgrade, Serbia \\ ${ }^{3}$ University of Nis, Faculty of Economics, Niš, Serbia \\ ${ }^{4}$ University for Criminalistic and Police Studies, Belgrade, Serbia \\ *milan.randjelovic@ntp.rs
}

\begin{abstract}
The key problem in the application of multi-criteria decision methods is to determine the importance of the criteria. That is the reason for the developing of a number of approaches for its calculation. Most of the used classifications divide them into two groups: subjective and objective. This paper presents an integration, an analytic hierarchy process (AHP) method as a subjective one, and the data envelopment analysis (DEA) method as an objective approach. The basic idea in the proposed procedure is to introduce objectivity into the process of criteria importance derivation with AHP by taking into account the weight obtained by DEA efficiency evaluation after introducing subjectivity in DEA, with an expert opinion.
\end{abstract}

Key words: Multi-criteria decision, criteria weights, business-friendly certification, AHP, DEA.

\section{ЈЕДНА ИНТЕГРИСАНА ДЕА/АХП МЕТОДОЛОГИЈА \\ ЗА ОДРЕБИВАЊЕ ЗНАЧАЈА КРИТЕРИЈУМА \\ У ПРОЦЕСУ ПОСЛОВНО-ПРИЈАТЕЉСКЕ ЦЕРТИФИКАЦИЈЕ НА ЛОКАЛНОМ НИВОУ}

\section{Апстракт}

Кључни проблем у примени вишекритеријумских метода одлучивања јесте утврдити важност критеријума. То је разлог за развој пуно приступа за њихов прорачун. Већина коришћених класификација дели методе на две групе: субјективне и објективне. У овом раду представљен је један метод ьихове интеграције, метода аналитичке хијерархије (АХП), као метода субјективне анализе, те метода анализе 
података (ДЕА), као објективног приступа. Основна идеја у предложеној процедури је увођење објективности у процес прорачуна важности критеријума са АХП методом узимајући у обзир тежине добијене помоћу процене ефикасности ДЕА методом пошто је претходно већ уведен субјективитет у ДЕА методу помоћу експертског мишљења.

Кључне речи: Вишекритеријумско одлучивање, тежине критеријума, пословно-пријатељска цертификација, АХП, ДЕА.

\section{INTRODUCTION}

For solving the uneven economic development in all of the municipalities in one country, we can involve the initiative to create a friendly business environment in the municipalities which can be achieved by identifying, and then presenting, the comparative advantages of the individual municipalities, with expected results - direct, reflected in the growth of investments, and indirect, increasing the living standards (Radukic, Stankovic \& Popovic 2012; Bfcsee, 2014). This task can be realized through the certification of cities and municipalities in which one of the most important tasks must be the determining of the significance of the criteria.

For solving this task, we have subjective assessments using the preference of authorities responsible for conducting certification, and another way is to define the objective approach based on the application of quantitative methods. It is important to notice that in the last few years, there has been a trend of integrating different methods of these two groups (Liu, 2003; Wang, Liu \& Elhag, 2008; Ramanathan, 2006, etc.), where the contributions of the authors of this paper is seen in their papers (Savić, Makajić-Nikolić, Ranđelović, Ranđelović, 2013; Ranđelović, Ranđelović, Savić Makajić-Nikolić, 2013).

The subject of this paper is the evaluation of the business-friendly certification (BFC) process in 21 cities of the Republic of Serbia for which task authors propose one procedure which integrates the data envelopment analysis (DEA) as objective, and the analytic hierarchy process (AHP) as the subjective approach, with the main objective being to improve the mentioned BFC process. For this task, theauthors hypothesized that there is no significant difference between the results obtained by the proposed method and the expert determination of the importance of particular criteria.

\section{LITERATURE REVIEW}

The problem of weight determination in MCDMs has existed since the formulation of the first MCDM (in Hwang, Yoon,1981; Saaty,1994; Zionts, 1992). As already mentioned, for the determination of the criteria importance, we have subjective approaches that reflect subjective judgment, and objective approaches which use mathematical methods (Ma, Fan, Huang, 1999). The most popular subjective approaches are AHP (Saaty, 1977; Saaty, 
1980; Saaty, 1994),the method of least squares comparison (Bozoki, 2008), the Delphi method (Sinuany-Stern, Abraham,Yossi, 2000; Seifert, Zhu, 1998), etc. The objective approaches include methods such as the linear programming techniques for the multidimensional analysis of privileged (LINMAP), various computer-aided mathematical models (Li, Chen, Huang, 2013), DEA (Podinovski, 1999; Charnes, Cooper, Rhodes, 1978; Banker, Charnes, Cooper, 1984; Cooper, Seiford, Tone, 2000), the entropy method (Shannon, Weaver, 1947; Ginevičius, Podvezko, 2004), the multi-attribute programming methods (Jahanshahloo, Zohrehbandian, Abbasian-Naghneh, 2011), the principal component analysis (Chen, Bai, 2013), etc.

In literature, we can find several methods for weight derivation which combine objective and subjective approaches, such as in Shang and Sueyoshi (1995) where the authors investigated excesses in Chinese industrial productivity in the period 1953-1990 by combining the DEA with other management scientific approaches among which was the AHP method. The weighed constant returns to scale (CRS), and the additive DEA model was used where the weights were obtained through expert opinion by the AHP approach. Their study showed that DEA could be combined, i.e. integrated with the AHP method to yield more valid results. In some papers we see that AHP was used first for handling subjective factors and for the generation of a set of numerical values, and then the DEA was used for identifying the efficiency score based on the entire data, including those generated by the AHP (Yang, Chunwei, 2003).

In research of Doyle and Green in 1993., the DEA was applied on pairs of units, and the resulting DEA scores were used for generating a pair-wise comparison matrix, and at the end, the AHP was applied to generate weights of units from the matrix. The AHP/DEA methodology for the facilities layout design problem was presented in research of Yang and Chunwei in 2003, so that the AHP was applied to collect the qualitative performance data, and the DEA was employed to identify the performance frontiers ordering the final candidate layout alternatives. Also, the AHP has been used to introduce preference information in the DEA calculations by Seifert and Zhu in 1998. One type of The AHP method - voting AHT method for supplier selection was presented in research of Liu and Hai in 2005, where the AHP determines the weight of criteria by voting and the DEA method was used for the aggregation of votes for each of the criteria received in different ranking places into an overall score for each individual criteria. In the research done by Ramanathan in 2006, the DEA generates local weights of alternatives from the pairwise comparison judgment matrices of the AHP and in research of Wang, Liu and Elhag i 2008) we have the integration of the DEA and AHP to prioritize the bridge structure considering the risk. 


\section{METHODS}

The authors of this paper propose one procedure which integrates the DEA and AHP approaches.

\section{Deriving Measures of Criteria Importance Using AHP Method}

The AHP is one of the most widely used decision-making methodologies in the world today. The AHP method is generally accepted in application (Saaty, 1994), as previously mentioned, because of its role in determining the weights in MCDM models.

The AHP is defined through a set of axioms that delimit the scope of the problem environment in reference (Saaty, 1994) as a multi-criteria analysis method. The mathematical foundation is a theory of consistent matrices and the ability of eigenvectors to generate true or approximate weights (Saaty, 1980). The AHP algorithm makes a comparison of criteria, or alternatives with respect to an observed criterion, in pairwise mode. As a tool for pairwise comparison, the AHP uses a fundamental scale of absolute numbers (from 1 to 9 ) that has been widely accepted in practice and validated by many different experiments in the field of decision theory. This scale has to be a scale that quantifies individual preferences with respect to quantitative and qualitative attributes just as well or better than other scales as was described by Saaty in 1977.

According to Saaty (Saaty, 1980), the AHP was founded on three design axioms: (i) the decomposition of the goal-value structure where a hierarchy of criteria, sub-criteria, and alternatives is developed, with the number of levels determined by the problem characteristics; (ii) the comparative judgments of the criteria on single pairwise comparisons of such criteria with respect to an upper criteria; and (iii) the linear-based synthesis of priorities where alternatives are evaluated in pairs with respect to the criteria on the next level of the hierarchy, and criteria can be given a priority (e.g. preference) expressed as a weight in the AHP matrix.

The problem is defined as a general problem of multi-criteria analysis where it is necessary to evaluate the $\mathrm{m}$ of available alternatives $A_{m}$ on the basis of $n$ relevant criteria $C_{n}$.

On the stage of decomposition, the problem is viewed as a hierarchical structure, where the goal is on the top, while the criteria by which a decision is made are treated at the lower levels. At the lowest hierarchical level, there is a range of alternatives, whose comparisons it is necessary to make. The next phase involves collecting data and peer evaluation. First of all, the pair-wise comparison of criteria and alternatives is made at a given level of hierarchy, but also in relation to the criteria of the directly higher level. The pairwise comparison of alternatives is done in response to the question of which of the two observed attributes that 
characterize an alternative to the given criteria is better in terms of meeting the criteria and its contribution to the certain objective. The strength of preference is expressed by the ratio scale with increments of 1-9. The preferential level of 1 shows equality of observed attributes, while the level of 9 indicates absolute, the strongest preference of one attribute over another (Forman, 1990; Cooper, Seiford, Tone, 2006). The result of the AHP application can be used to compare the importance of the criteria, as well as the rank of alternatives.

Based on pairwise comparison, the reciprocal matrix (dimension $\mathrm{n} \times \mathrm{n}$ on the level of criteria, or $\mathrm{m} \mathrm{x} \mathrm{m}$ on the level of alternatives) can be formed, where the elements $a_{i i}=1$, while the elements $a_{j i}$ are the reciprocal of the elements $a_{i j}$, i.e. $a_{j i}=1 / a_{i j}, i \neq j$ and $i, j=1,2, \ldots, n$. Another important issue when it comes to pairwise comparison is the consistency of decision maker preferences. Namely, if the consistency is perfect then the following is fulfilled: if criterion $\mathrm{C}_{\mathrm{x}}$ is equally important to another criterion $\mathrm{C}_{\mathrm{y}}(\mathrm{x} \neq \mathrm{y}$ and $\mathrm{x}, \mathrm{y}\{1,2, \ldots, \mathrm{n}\})$ than the pairwise comparison matrix will contain value of $\mathrm{a}_{\mathrm{xy}}=1=\mathrm{a}_{\mathrm{yx}}$, and at the same time the criterion $\mathrm{C}_{\mathrm{y}}$ is absolutely more important than the criterion $\mathrm{C}_{\mathrm{z}}$ and the pairwise comparison matrix contains values $\mathrm{a}_{\mathrm{yz}}=9$ and $\mathrm{a}_{\mathrm{zy}}=1 / 9(\mathrm{y} \neq \mathrm{z}$ and $\mathrm{y}, \mathrm{z}\{1,2, \ldots, \mathrm{n}\})$, then the criterion $\mathrm{C}_{\mathrm{x}}$ should also be absolutely more important than the criterion $C_{z}$ i.e. $a_{x z}=9$ and $\mathrm{a}_{\mathrm{zx}}=1 / 9$ see (Leskinen, 2000; Ma, Zhang, 1991). However, the decision maker is often not able to express consistent preferences in case of several criteria. The Saaty's method for measuring the inconsistency of the pairwise comparison matrix can be understood as explaining that in an ideal case when the comparison matrix (A) is fully consistent, the matrix rank (A) is equal to 1 , and its eigenvalue $\lambda$ is equal to $n$, i.e. to the number of criteria.

Consistency index (CI) and the consistency ratio (CR) can be calculated as it is given in (Cooper, Seiford, Tone, 2000):

$$
\begin{gathered}
\mathrm{CI}=\frac{\lambda_{\text {max }}-n}{n-1} \\
\mathrm{CR}=\frac{C I}{R I}
\end{gathered}
$$

The RI is the random index representing the average value of $\mathrm{CI}$ in randomly generated pairwise comparison matrix using the Saaty scale obtained by Forman and Saaty, and accepts a matrix as a consistent one only if CR < 0.1, as it was presented by Forman in 1990. And by Alonso and Lamata in 2006. 


\section{DERIVING MEASURES OF CRITERIA IMPORTANCE USING DEA METHOD}

As is known, the DEA has been widely used for evaluating the relative performance of similar DMUs with multiple inputs and outputs. The original efficiency definition given in papers of Li, Chen and Huang in 2013. generalizes the single-input to single-output ratio in the definition of efficiency as the ratio of the sum of the weighted outputs, to the sum of the weighted inputs. Suppose that $\operatorname{DMU}_{j}(j=1, \ldots, n)$, within a set of $n$ units, uses inputs $\mathrm{x}_{\mathrm{ij}}(\mathrm{i}=1, \ldots, \mathrm{m})$ to produce outputs $\mathrm{y}_{\mathrm{rj}}(\mathrm{r}=1, \ldots, \mathrm{s})$, the absolute efficiency measure model is as follows (Podinovski, 1999):

$$
E_{j}=\frac{\sum_{r=1}^{s} u_{r} y_{r j}}{\sum_{i=1}^{m} v_{i} x_{i j}}
$$

where $\mathrm{v}_{\mathrm{i}}(\mathrm{i}=1, \ldots, \mathrm{m})$ are input multipliers and $\mathrm{u}_{\mathrm{r}}(\mathrm{r}=1, \ldots, \mathrm{s})$ are output multipliers (weights).

The above definition corresponds to a discrete MCDM. The determination of weights is a very sensitive and complicated process. The weights selected a priori, as in MCDM models, can significantly affect the results of the efficiency calculation. Following that idea, the authors of the DEA model in reference (Charnes, Cooper, Rhodes, 1978) allowed each DMU to choose the most appropriate set of weights in order to become as efficient as possible in comparison with the other units in the observing set. The relative efficiency ratio is scaled between 0 and 1 , and all efficient units have the same ratio equal to 1 . The linear programming (LP), the weighed form of the basic constant return to scale model is as follows:

$$
(\max ) \mathrm{h}_{k}=\sum_{r=1}^{s} u_{r} y_{r k}
$$

such that

$$
\begin{gathered}
\sum_{i=1}^{m} v_{i} x_{i j}=1 \\
\sum_{r=1}^{s} u_{r} y_{r j}-\sum_{i=1}^{m} v_{i} x_{i j}<0, j=1, \ldots, n \\
v_{i} \geq \varepsilon, \mathrm{i}=1, \ldots, \mathrm{m} ; u_{r} \geq \varepsilon, \mathrm{r}=1, \ldots, \mathrm{s}
\end{gathered}
$$

The optimal values of efficiency scores $h_{k}$ are obtained by solving the linear model given with equations (4) - (7) $\mathrm{n}$ - times (once for each DMU in order to compare it with other DMUs). As a solution of basic CCR based on DEA models (Charnes, Cooper, Rhodes, 1978), efficiency score $h_{k}$ is 1 for all efficient units and lower than 1 for all inefficient units. All inefficient units are enveloped by production frontier, consist of efficient 
DMUs, and for each of them an analyst could find the benchmark (realefficient or virtual-composite peer unit lying on the efficiency frontier) (Banker, Charnes, Cooper, 1984).

In researchof Ramanathan from 2006. it is claimed that, when the DEA is used for aggregation, the importance measures of the criteria are automatically generated by the DEA as the values of multipliers using linear programming. In that study, a simple DEA model with one dummy input is used to get the composite weights of alternatives (DMUs). In this paper, we obtained the following weight matrix:

$$
Z=\left[z_{j i}\right]_{n \times(\mathrm{s}+\mathrm{m})}=\left[\begin{array}{cc}
u_{11} \ldots u_{1 s} & \mathrm{v}_{11} \ldots v_{1 m} \\
& \vdots \\
u_{n 1} \ldots u_{n s} & \mathrm{v}_{n 1} \ldots v_{n n}
\end{array}\right]
$$

where $\mathrm{z}_{\mathrm{ji}}$ are the weights of decision alternatives, $\operatorname{DMUj}(\mathrm{j}=1, \ldots, \mathrm{n})$, with respect to the criterion $i(i=1, \ldots, s+m)$.

\section{THE AGGREGATION COMPOSITE WEIGHTS FOR THE CRITERIA IMPORTANCE}

Having in mind that this paper will consider the case study with a significantly large number of input, the criterion which can be perceived as the output criterion in suitable inverted DEA model and the proposed theorem in the research of Ramanathan in 2006., the authors propose that the composite weights calculation should include the subjectively obtained local weights $\omega_{i}^{*}$ each of which would represent the output criterion and matrix $\mathrm{Z}^{*}$ as follows:

$$
Z^{*}=\left[z_{j i}^{*}\right]_{n \times(\mathrm{s}+\mathrm{m})}=\left[\begin{array}{cc}
u_{11} \ldots u_{1 s} & \mathrm{v}_{11} \omega_{1}^{*} \ldots v_{1 m} \omega_{m}^{*} \\
\vdots \\
u_{n 1} \ldots u_{n s} & \mathrm{v}_{n 1} \omega_{1}^{*} \ldots v_{n m} \omega_{m}^{*}
\end{array}\right]
$$

where subjective weights can be given as simple judgements of experts, as it is applied in the proposed case. Additionally, they can be obtained with certain subjective methods (as for example the AHP).

The average importance values for each criterion can be calculated based on the given matrix

$$
\bar{Z}_{i}^{*}=\sum_{j=1}^{n} z_{i j}^{*}, \mathrm{n}, \mathrm{i}=1, \ldots, \mathrm{s}+\mathrm{m}
$$

The composite relative weights represent the normalized value of $\bar{Z}_{i}^{*}, \mathrm{i}=1, \ldots, \mathrm{s}+\mathrm{m}$. 


\section{RESULTS}

In Serbia, the BFC process has been carried out since 2007 and it is implemented by the Serbian National Alliance for Local Economic Development (NALED) in 21 cities and municipalities in Serbia that have completed this process successfully. The relevant criteria for BFC in the cities of Serbia, according to NALED's methodology are (Naled-Serbia, 2012; Certification program business-friendly municipality, 2012):

C1: The strategic planning of local economic development in partnership with businesses

C2: The special department in charge of the local economic development (LED), FDI promotion and business support - existence of LED Office

C3: The business council for economic issues - the advisory body to the local governments

C4: The efficient and transparent system for acquiring construction permits

C5: The economic data and the information relevant for starting and developing a business

C6: The multilingual marketing materials and website

C7: The balanced structure of budget revenues and/or debt management

C8: The investment into the development of the local workforce

C9: The cooperation and joint projects with local business on fostering LED

C10: The adequate infrastructure and reliable communal services

C11: The transparent policies on local taxes and incentives for doing business

C12: The electronic communication and on-line services

The BFC process is an iterative procedure which consists of the steps given in Figure 1. The importance of the criteria $\mathrm{w}_{\mathrm{j}}$ is defined as the average score of the previous level of evaluation and as such can be called the relative importance of observed criteria $C_{j}, j=1,2, . ., n$. The data about the significance evaluation of all the relevant certification criteria in the model, according to the methodology, as applied by the local and state governments, in this particular study for the certification of 21 cities in Republic of Serbia, are given in Table 1. Since multi-criteria analysis models include the application of weights such as $\sum_{j=1}^{n} \omega_{j}=1$, where $\omega_{\mathrm{j}}$ is weight that expresses the relative importance of the criteria $\mathrm{C}_{\mathrm{j}}$, $\mathrm{j}=1,2, . ., 12$, the results generated by the methodology of the local governments must be adapted by using the appropriate additive normalization like in Table 1 (Naled-Serbia, 2012; Savić, Makajić-Nikolić, Ranđelović, Ranđelović, 2013). 


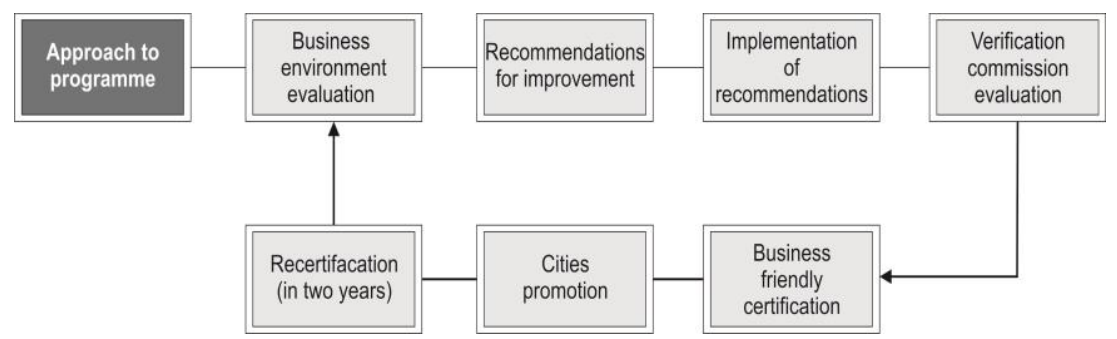

Figure 1. BFC process scheme, source Naled-Serbia

Table 1. The criteria weights according to the methodology of the local governments

\begin{tabular}{lcccccccccccc}
\hline & $\mathrm{C}_{1}$ & $\mathrm{C}_{2}$ & $\mathrm{C}_{3}$ & $\mathrm{C}_{4}$ & $\mathrm{C}_{5}$ & $\mathrm{C}_{6}$ & $\mathrm{C}_{7}$ & $\mathrm{C}_{8}$ & $\mathrm{C}_{9}$ & $\mathrm{C}_{10}$ & $\mathrm{C}_{11}$ & $\mathrm{C}_{12}$ \\
\hline $\begin{array}{l}\text { Importance } \\
\text { according to }\end{array}$ & 1.25 & 0.90 & 0.67 & 1.19 & 0.66 & 0.71 & 1.00 & 0.75 & 1.08 & 1.21 & 1.50 & 0.83 \\
$\begin{array}{l}\text { NALED } \\
\text { Additive Normalized } \\
\text { Relative Weights } \omega_{i}^{*}\end{array}$ & 0.11 & 0.08 & 0.06 & 0.10 & 0.06 & 0.06 & 0.09 & 0.06 & 0.09 & 0.10 & 0.13 & 0.07 \\
\hline
\end{tabular}

Source: Authors' review according to NALED

Table2. Relevant criteria

\begin{tabular}{|c|c|c|c|c|c|c|c|c|c|c|c|c|c|}
\hline & $\mathrm{Cl}$ & $C 2$ & $C 3$ & $C 4$ & $C 5$ & C6 & $C 7$ & $C 8$ & $C 9$ & $C 10$ & $C 11$ & C12 & $\begin{array}{l}\text { Average per } \\
\text { Municipality }\end{array}$ \\
\hline $\begin{array}{c}\text { Criterion } \\
\text { Type }\end{array}$ & $\max$ & $\max$ & $\max$ & $\max$ & $\max$ & $\max$ & $\max$ & $\max$ & $\max$ & $\max$ & $\max$ & $\max$ & $\max$ \\
\hline 1 Mun. 1 & 0.800 & 1.059 & 1.000 & 0.732 & 0.875 & 1.000 & 1.000 & 0.733 & 0.636 & 0.829 & 1.000 & 1.250 & 0.910 \\
\hline Mun. 2 & 1.000 & 0.824 & 0.750 & 1.000 & 0.925 & 1.000 & 1.000 & 0.933 & 1.000 & 0.878 & 1.000 & 1.000 & 0.943 \\
\hline 3 Mun. 3 & 0.625 & 0.947 & 0.800 & 0.941 & 0.857 & 1.182 & 0.900 & 0.750 & 0.667 & 0.940 & 0.929 & 1.100 & 0.887 \\
\hline 4 Mun. 4 & 0.900 & 0.824 & 0.875 & 1.000 & 0.950 & 1.000 & 1.000 & 0.700 & 0.682 & 0.756 & 1.000 & 0.750 & 0.870 \\
\hline Mun. 5 & 1.000 & 0.618 & 1.000 & 0.780 & 0.600 & 0.667 & 1.000 & 0.600 & 0.591 & 0.976 & 0.833 & 1.250 & 0.826 \\
\hline 6 Mun. 6 & 1.000 & 1.059 & 0.750 & 0.939 & 0.900 & 0.944 & 1.000 & 0.867 & 0.909 & 0.793 & 1.000 & 1.250 & 0.951 \\
\hline 7 Mun. 7 & 1.000 & 0.941 & 1.000 & 0.780 & 0.700 & 0.778 & 1.000 & 0.567 & 0.727 & 0.695 & 1.000 & 0.500 & 0.807 \\
\hline Mun. 8 & 1.000 & 0.824 & 1.000 & 0.890 & 1.000 & 1.056 & 1.000 & 0.833 & 0.545 & 0.878 & 1.000 & 1.250 & 0.940 \\
\hline 9 Mun. 9 & 1.000 & 0.824 & 1.000 & 0.671 & 0.650 & 1.000 & 1.000 & 0.867 & 0.955 & 0.805 & 0.833 & 1.000 & 0.884 \\
\hline 10 Mun.10 & 1.000 & 0.941 & 0.750 & 0.808 & 0.625 & 0.944 & 1.000 & 0.667 & 0.909 & 0.793 & 1.000 & 1.000 & 0.870 \\
\hline 11 Mun.11 & 1.000 & 0.765 & 0.750 & 0.829 & 0.725 & 1.000 & 1.000 & 0.533 & 0.636 & 0.756 & 0.833 & 1.250 & 0.840 \\
\hline 12 Mun.12 & 0.800 & 1.000 & 0.750 & 0.890 & 0.900 & 1.000 & 1.000 & 0.533 & 0.727 & 0.732 & 0.833 & 0.750 & 0.826 \\
\hline 13 Mun.13 & 0.800 & 1.000 & 1.000 & 0.744 & 0.725 & 1.000 & 1.000 & 0.767 & 0.455 & 0.768 & 1.000 & 1.000 & 0.855 \\
\hline 14 Mun.14 & 1.000 & 0.941 & 1.000 & 0.866 & 0.725 & 1.000 & 1.000 & 0.833 & 0.545 & 0.683 & 1.000 & 0.875 & 0.872 \\
\hline 15 Mun.15 & 1.000 & 0.941 & 1.000 & 1.000 & 0.900 & 1.000 & 1.000 & 1.000 & 1.000 & 0.939 & 1.000 & 0.623 & 0.950 \\
\hline 16 Mun.16 & 1.000 & 0.824 & 1.000 & 0.890 & 0.775 & 1.000 & 1.000 & 0.800 & 0.909 & 0.780 & 1.000 & 1.000 & 0.915 \\
\hline 17 Mun.17 & 1.000 & 0.824 & 1.000 & 0.780 & 0.875 & 0.889 & 1.000 & 0.667 & 0.545 & 0.829 & 0.667 & 0.750 & 0.819 \\
\hline 18 Mun.18 & 1.000 & 0.882 & 1.000 & 1.024 & 0.900 & 0.944 & 1.000 & 0.867 & 1.091 & 0.927 & 1.000 & 1.000 & 0.970 \\
\hline 19 Mun.19 & 0.938 & 1.000 & 1.000 & 0.944 & 0.929 & 1.000 & 1.000 & 0.850 & 0.833 & 0.780 & 1.000 & 1.000 & 0.940 \\
\hline 20 Mun.20 & 1.000 & 0.947 & 0.600 & 0.972 & 0.929 & 1.000 & 1.000 & 0.850 & 0.583 & 0.940 & 1.000 & 1.000 & 0.902 \\
\hline 21 Mun.21 & 1.000 & 0.765 & 0.875 & 0.805 & 0.800 & 1.000 & 1.000 & 0.733 & 0.818 & 0.768 & 1.000 & 1.000 & 0.880 \\
\hline $\begin{array}{l}\text { Average } \\
\text { level per } \\
\text { criterion }\end{array}$ & 0.946 & 0.889 & 0.900 & 0.871 & 0.822 & 0.960 & 0.995 & 0.760 & 0.751 & 0.821 & 0.949 & 0.933 & 0.883 \\
\hline
\end{tabular}

Source: Authors' review according to NALED 
It is exactly this evaluation of the criteria of importance in the model that will be the subject of the re-evaluation by the application of appropriate methods. As stated, the idea of the authors is to perform an aggregation of DEA and AHP to determine the weight of a particular criterion. In its first step, this procedure includes the subjectively obtained judgements from NALED experts in the aggregated DEA method, thus making one closed circle of subjectivization of DEA, as one objective method, and the objectification of AHP as one subjective method. To protect the interests of the 21 cities in the last NALED report, the results of the BFC process are presented without highlighting their names (Table 2 ) including the investments per population in the cities shown in Table 3 (Statistical Office of the Republic of Serbia, Municipalities and Regions in the Republic of Serbia in 2012, 2012).

Table 3. Investment per capita

\begin{tabular}{|c|c|c|c|c|c|}
\hline & \multicolumn{3}{|c|}{ Realized investments in fixed assets in $€$} & \multirow{2}{*}{ Population } & \multirow{2}{*}{$\begin{array}{l}\text { Investment } \\
\text { per capita }\end{array}$} \\
\hline & 2009 & 2010 & $\begin{array}{c}\text { Total for period } \\
2009-2011\end{array}$ & & \\
\hline 1 Municipality 1 & $41,633,640.00$ & $18,326,250.00$ & $59,959,890.00$ & 115,303 & 520.020 \\
\hline 2 Municipality 2 & $105,575,220.00$ & $69,980,070.00$ & $175,555,290.00$ & 255,699 & 686.570 \\
\hline 3 Municipality 3 & $17,706,400.00$ & $14,492,600.00$ & $32,199,000.00$ & 55,454 & 580.643 \\
\hline 4 Municipality 4 & $15,044,760.00$ & $12,462,680.00$ & $27,507,440.00$ & 59,263 & 464.159 \\
\hline 5 Municipality 5 & $12,124,350.00$ & $13,429,050.00$ & $25,553,400.00$ & 80,881 & 315.938 \\
\hline 6 Municipality 6 & $51,600,930.00$ & $35,555,310.00$ & $87,156,240.00$ & 92,487 & 942.362 \\
\hline 7 Municipality 7 & $62,219,040.00$ & $13,755,290.00$ & $75,974,330.00$ & 86,413 & 879.200 \\
\hline 8 Municipality 8 & $20,515,800.00$ & $7,593,520.00$ & $28,109,320.00$ & 67,576 & 415.966 \\
\hline 9 Municipality 9 & $42,270,770.00$ & $79,628,490.00$ & $121,899,260.00$ & 195,681 & 622.949 \\
\hline 10 Municipality 10 & $75,072,730.00$ & $37,136,250.00$ & $112,208,980.00$ & 148,801 & 754.088 \\
\hline 11 Municipality 11 & $55,099,500.00$ & $33,956,900.00$ & $89,056,400.00$ & 129,568 & 687.333 \\
\hline 12 Municipality 12 & $5,386,570.00$ & $7,807,540.00$ & $13,194,110.00$ & 65,969 & 200.005 \\
\hline 13 Municipality 13 & $2,386,480.00$ & $2,453,770.00$ & $4,840,250.00$ & 43,302 & 111.779 \\
\hline 14 Municipality 14 & $10,160,350.00$ & $21,980,000.00$ & $32,140,350.00$ & 87,288 & 368.210 \\
\hline 15 Municipality 15 & $34,216,960.00$ & $15,184,540.00$ & $49,401,500.00$ & 49,609 & 995.817 \\
\hline 16 Municipality 16 & $14,883,070.00$ & $17,722,980.00$ & $32,606,050.00$ & 156,252 & 208.676 \\
\hline 17 Municipality 17 & $10,654,430.00$ & $7,742,220.00$ & $18,396,650.00$ & 60,006 & 306.580 \\
\hline 18 Municipality 18 & $17,777,610.00$ & $21,084,270.00$ & $38,861,880.00$ & 131,368 & 295.825 \\
\hline 19 Municipality 19 & $319,581,580.00$ & $407,635,680.00$ & $727,217,260.00$ & 299,294 & $2,429.776$ \\
\hline 20 Municipality 20 & $23,588,600.00$ & $23,872,440.00$ & $47,461,040.00$ & 109,809 & 432.214 \\
\hline 21 Municipality 21 & $27,176,670.00$ & $30,699,490.00$ & $57,876,160.00$ & 83,022 & 697.118 \\
\hline Total & $964,675,460.00$ & $892,499,340.00$ & $1,857,174,800.00$ & $2,373,045$ & \\
\hline Average & $45,936,926.67$ & $42,499,968.57$ & $88,436,895.24$ & 113,002 & 610.906 \\
\hline
\end{tabular}

Source: Authors' review according to the Statistical Office of the Republic of Serbia

In the following section, the proposed procedure, based on DEA methodology, will be used to measure the efficiency of the observed municipalities in attracting foreign direct investment, as well as the measure of certain criteria of importance in achieving the goal defined as the highest possible amount of investment per capita in the municipality. The logic is simple - if the criterion of importance is higher, the relative 
importance is higher as well. This logic will also be used as the basis for pairwise comparison in the AHP model.

\section{CRITERIA IMPORTANCE DERIVATION WITH DEA METHOD}

As it is mentioned, the first step in the methodology presented in the second section is a relative efficiency evaluation of all the observed DMUs (municipalities). In this case, the inverted DEA model is used in order to determine the BFC criteria importance (output weights). Naturally, the level of criteria fulfilment would have an impact on the level of investments. Contrary to this, we considered the investments as an input and the BFC criteria are considered as outputs for the purpose of the analyses. The DEA-solver software (Cooper, Seiford, Tone, 2006) is applied for efficiency evaluation. The efficiency indexes and criteria (inputs and outputs) weights for each DMU are obtained as a result of applying the DEA model with variable return to scale (VRS) assumption presented in Table 4.

Table 4. DEA mulitiliers $Z_{j i}$

\begin{tabular}{|c|c|c|c|c|c|c|c|c|c|c|c|c|c|}
\hline & $\{\mathrm{I}\}$ & $\begin{array}{l}\mathrm{C} 1 \\
\{\mathrm{O}\}\end{array}$ & $\begin{array}{l}\mathrm{C} 2 \\
\{\mathrm{O}\}\end{array}$ & $\begin{array}{c}\mathrm{C} 3 \\
\{\mathrm{O}\}\end{array}$ & $\begin{array}{c}\mathrm{C} 4 \\
\{\mathrm{O}\}\end{array}$ & $\begin{array}{l}\mathrm{C} 5 \\
\{\mathrm{O}\}\end{array}$ & $\begin{array}{c}\mathrm{C} 6 \\
\{\mathrm{O}\}\end{array}$ & $\begin{array}{c}\mathrm{C} 7 \\
\{\mathrm{O}\}\end{array}$ & $\begin{array}{c}\mathrm{C} 8 \\
\{\mathrm{O}\}\end{array}$ & $\begin{array}{c}\mathrm{C} 9 \\
\{\mathrm{O}\}\end{array}$ & $\begin{array}{l}\mathrm{C} 10 \\
\{\mathrm{O}\}\end{array}$ & $\begin{array}{l}\mathrm{C} 11 \\
\{\mathrm{O}\}\end{array}$ & $\begin{array}{l}\mathrm{C} 12 \\
\{\mathrm{O}\}\end{array}$ \\
\hline Municip. 1 & 0.0019 & 0.0000 & 0.0000 & 0.2857 & 0.0000 & 0.0000 & 0.0000 & 0.0000 & 0.0000 & 0.0000 & 0.0000 & 0.0000 & 0.5714 \\
\hline Municip. 2 & & 0.0000 & 0.0000 & 0.0000 & 0.0000 & 0.0000 & 0.0000 & 0.0000 & 0.7777 & 0.0000 & 0.0000 & 0.0000 & 0.2744 \\
\hline Municip. 3 & 0 . & 0.0000 & 0.0000 & 0.0035 & 0.1101 & 0.0000 & 0.0000 & 0.0000 & 0.0000 & 0.0000 & 0.5485 & 0.0000 & 0.343 \\
\hline Municip. 4 & & 0.0000 & 0.0000 & 0.0000 & 0.3783 & 0.4289 & 0.2142 & 0.0000 & 0.0000 & 0.0000 & 0.0000 & 0.0000 & 0.0000 \\
\hline Municip. 5 & & 0.0000 & 0.0000 & 0.0223 & 0.0000 & 0.0000 & 0.0000 & 0.0000 & 0.0000 & 0.0000 & 1.0017 & 0.0000 & 0.0000 \\
\hline Municip. 6 & & 0.3400 & 0.6059 & 0.0000 & 0.0008 & 0.0000 & 0.0000 & 0.0000 & 0.0000 & 0.0194 & 0.0000 & 0.0000 & 0.000 \\
\hline Municip. 7 & & 0.3042 & 0.2194 & 0.3096 & 0.0000 & 0.0000 & 0.0000 & 0.0694 & 0.0000 & 0.0000 & 0.0000 & 0.1103 & 0.0000 \\
\hline Municip. 8 & & 0.0000 & 0.0000 & 0.0476 & 0.0000 & 0.8348 & 0.0000 & 0.0000 & 0.0000 & 0.0000 & 0.0000 & 0.0000 & 0.117 \\
\hline Municip. 9 & 0.0 & 0.0496 & 0.0000 & 0.1475 & 0.0000 & 0.0000 & 0.3981 & 0.0000 & 0.2763 & 0.0227 & 0.0000 & 0.0000 & 0.1436 \\
\hline Municip. 10 & & 0.3621 & 0.0000 & 0.0000 & 0.0000 & 0.0000 & 0.0000 & 0.1167 & 0.0000 & 0.0000 & 0.0000 & 0.2799 & 0.2413 \\
\hline ip. 11 & & 0.4370 & 0.0000 & 0.0000 & 0.0000 & 0.0000 & 0.2958 & 0.0893 & 0.0000 & 0.0000 & 0.0000 & 0.0000 & 0.1779 \\
\hline ip. 12 & & 0.0000 & 0.0000 & 0.0000 & 0.0000 & 1.1111 & 0.0000 & 0.0000 & 0.0000 & 0.0000 & 0.0000 & 0.0000 & 0.0000 \\
\hline p. 13 & & 0.056 & 0.0029 & 0.1122 & 0.0276 & 0.0248 & 0.0567 & 0.0601 & 0.0612 & 0.0308 & 0.1460 & 0.2662 & 0.244 \\
\hline . 14 & & 0.3151 & 0.3310 & 0.1071 & 0.0000 & 0.0000 & 0.2663 & 0.0000 & 0.0000 & 0.0000 & 0.0000 & 0.0000 & 0.0000 \\
\hline . 15 & & 0.0000 & 0.0000 & 0.2089 & 0.0000 & 0.0000 & 0.0000 & 0.0000 & 0.7911 & 0.0000 & 0.0000 & 0.0000 & 0.0000 \\
\hline ip. 16 & 0.0048 & 0.0000 & 0.0000 & 0.0000 & 0.0000 & 0.0000 & 0.0000 & 0.0000 & 0.0000 & 1.1001 & 0.0000 & 0.0000 & 0.0000 \\
\hline p. 17 & & 0.3624 & 0.0000 & 0.4579 & 0.0000 & 0.0000 & 0.0000 & 0.1797 & 0.0000 & 0.0000 & 0.0000 & 0.0000 & 0.0000 \\
\hline 18 & & 0.0000 & 0.0000 & 0.0000 & 0.0000 & 0.0000 & 0.0000 & 0.0000 & 0.0000 & 0.9166 & 0.0000 & 0.0000 & 0.0000 \\
\hline ip. 19 & 0.0004 & 0.0000 & 0.2892 & 0.1467 & 0.1708 & 0.3966 & 0.0000 & 0.0000 & 0.0000 & 0.0000 & 0.0000 & 0.0000 & 0.0344 \\
\hline ip. 20 & & 0.0686 & 0.1441 & 0.0000 & 0.0000 & 0.0000 & 0.5263 & 0.0000 & 0.0000 & 0.0000 & 0.2858 & 0.0000 & 0.0000 \\
\hline Municip. 21 & & 0.3931 & 0.0000 & 0.0000 & 0.0000 & 0.0000 & 0.1686 & 0.0915 & 0.0000 & 0.0000 & 0.0000 & 0.1863 & 0.1606 \\
\hline$\omega_{i}^{*}$ & & 0.11 & 0.08 & 0.06 & 0.10 & 0.06 & 0.06 & 0.09 & 0.06 & 0.09 & 0.10 & 0.13 & 0.07 \\
\hline $\bar{Z}_{i}^{*}$ & & 0.1727 & 0.0744 & 0.0648 & 0.0401 & 0.0980 & 0.0675 & 0.0319 & 0.0668 & 0.1098 & 0.1157 & 0.0640 & 0.0943 \\
\hline
\end{tabular}

The results given in Table 4 have been considered as the matrix $\mathrm{Z}$, and have been used as the basis for composite weights calculation according to Eq. 9. Each element $z_{\mathrm{ji}}$ is calculated as the product of corresponding element in Table 4 and Additive Normalized Relative 
Weights $\left(\omega_{i}^{*}\right)$ (Table 1). Finally, the normalized average weights are calculated according to eq. 10 and given in the last row of Table 4 .

\section{CRITERIA IMPORTANCE DERIVATION WITH THE AHP METHOD USING OBTAINED WEIGHTS WITH THE DEA}

Using the average weights $\bar{Z}_{i}^{*}$ obtained by the DEA method, the pairwise comparison matrix has been formed (Table 5), which has acceptable inconsistency because the consistency index is $\mathrm{CI}<0.1$. The higher relative weight $\bar{Z}_{i}^{*}$ results imply the higher preference in 1-9 Saaty's scale for pairwise comparison.

Table 5. Pairwise comparison matrix

\begin{tabular}{lcccccccccccc}
\hline & $\mathrm{c} 1$ & $\mathrm{c} 2$ & $\mathrm{c} 3$ & $\mathrm{c} 4$ & $\mathrm{c} 5$ & $\mathrm{c} 6$ & $\mathrm{c} 7$ & $\mathrm{c} 8$ & $\mathrm{c} 9$ & $\mathrm{c} 10$ & $\mathrm{c} 11$ & $\mathrm{c} 12$ \\
\hline $\mathrm{c} 1$ & 1 & 3 & 3 & 9 & $9 / 5$ & 3 & 9 & 3 & $9 / 5$ & $9 / 7$ & 3 & $9 / 5$ \\
$\mathrm{c} 2$ & $1 / 3$ & 1 & 1 & 3 & $3 / 5$ & 1 & 3 & 1 & $3 / 5$ & $3 / 7$ & 1 & $3 / 5$ \\
$\mathrm{c} 3$ & $1 / 3$ & 1 & 1 & 3 & $3 / 5$ & 1 & 3 & 1 & $3 / 5$ & $3 / 7$ & 1 & $3 / 5$ \\
$\mathrm{c} 4$ & $1 / 9$ & $1 / 3$ & $1 / 3$ & 1 & $1 / 5$ & $1 / 3$ & 1 & $1 / 3$ & $1 / 5$ & $1 / 7$ & $1 / 3$ & $1 / 5$ \\
$\mathrm{c} 5$ & $5 / 9$ & $5 / 3$ & $5 / 3$ & 5 & 1 & $5 / 3$ & 5 & $5 / 3$ & 1 & $5 / 7$ & $5 / 3$ & 1 \\
$\mathrm{c} 6$ & $1 / 3$ & 1 & 1 & 3 & $3 / 5$ & 1 & 3 & 1 & $3 / 5$ & $3 / 7$ & 1 & $3 / 5$ \\
$\mathrm{c} 7$ & $1 / 9$ & $1 / 3$ & $1 / 3$ & 1 & $1 / 5$ & $1 / 3$ & 1 & $1 / 3$ & $1 / 5$ & $1 / 7$ & $1 / 3$ & $1 / 5$ \\
$\mathrm{c} 8$ & $1 / 3$ & 1 & 1 & 3 & $3 / 5$ & 1 & 3 & 1 & $3 / 5$ & $3 / 7$ & 1 & $3 / 5$ \\
$\mathrm{c} 9$ & $5 / 9$ & $5 / 3$ & $5 / 3$ & 5 & 1 & $5 / 3$ & 5 & $5 / 3$ & 1 & $5 / 7$ & $5 / 3$ & 1 \\
$\mathrm{c} 10$ & $7 / 9$ & $7 / 3$ & $7 / 3$ & 7 & $7 / 5$ & $7 / 3$ & 7 & $7 / 3$ & $7 / 5$ & 1 & $7 / 3$ & $7 / 5$ \\
$\mathrm{c} 11$ & $1 / 3$ & 1 & 1 & 3 & $3 / 5$ & 1 & 3 & 1 & $3 / 5$ & $3 / 7$ & 1 & $3 / 5$ \\
$\mathrm{c} 12$ & $5 / 9$ & $5 / 3$ & $5 / 3$ & 5 & 1 & $5 / 3$ & 5 & $5 / 3$ & 1 & $5 / 7$ & $5 / 3$ & 1 \\
\hline \multicolumn{7}{l}{ Source: The author's calculations with SANNA 2014 AHP software $(w w w . n b . v s e . c z)$}
\end{tabular}

The AHP method has been used to calculate weights that include an objective component - the weight of criteria derived in the DEA procedure (Table 6). This step represents an aggregation of two methods, the DEA and the AHP.

Table 6. Weights calculation using AHP method

\begin{tabular}{lcccccccccccc}
\hline & $\mathrm{c} 1$ & $\mathrm{c} 2$ & $\mathrm{c} 3$ & $\mathrm{c} 4$ & $\mathrm{c} 5$ & $\mathrm{c} 6$ & $\mathrm{c} 7$ & $\mathrm{c} 8$ & $\mathrm{c} 9$ & $\mathrm{c10}$ & $\mathrm{c11}$ & $\mathrm{c12}$ \\
\hline Additive & & & & & & & & & & & & \\
$\begin{array}{l}\text { Normalized } \\
\text { Weights }\end{array}$ & 0,19 & 0,06 & 0,06 & 0,02 & 0,1 & 0,06 & 0,02 & 0,06 & 0,1 & 0,15 & 0,06 & 0,1 \\
\hline
\end{tabular}

\section{DISCUSSION}

Results discussion is based on the comparisons of weights obtained by the additive normalizing using the relative importance of the criteria determined by NALED, and the local self-governments (Table 1), and the results obtained in the procedure proposed, and presented in this paper 
(Table 6), with the aim to indicate the practical implications of the applied procedures and the obtained results. In fact the proposed procedure introduces objectivity into the process of criteria importance derivation with the AHP by taking into account the weights obtained by the DEA efficiency evaluation after introducing subjectivity in the DEA with an expert opinion.

The T-test is used as a statistical tool, as it provides the simplest way to determine a possible difference of the results obtained by the proposed method compared to the one proposed by experts.

Table 7. Paired Samples Statistics

\begin{tabular}{ccllr}
\hline $\begin{array}{c}\text { Naled } \\
\text { Weights }\end{array}$ & $\begin{array}{c}\text { Proposed } \\
\text { Method } \\
\text { Weights }\end{array}$ & \multicolumn{1}{c}{$\begin{array}{c}\text { t-Test: Paired Two Sample } \\
\text { for Means }\end{array}$} & & \\
\hline 0,11 & 0,19 & & & \\
0,08 & 0,06 & & 0,084166667 & 0,081666667 \\
0,06 & 0,06 & Mean & 0,000535606 & 0,002487879 \\
0,1 & 0,02 & Variance & 12 & 12 \\
0,06 & 0,1 & Observations & 0,206071706 & \\
0,06 & 0,06 & Pearson Correlation & 11 & \\
0,09 & 0,02 & Hypothesized Mean Difference & 0,171575062 & \\
0,06 & 0,06 & Df & 0,433443621 & \\
0,09 & 0,1 & t Stat & 1,795884819 & \\
0,1 & 0,15 & P(T<=t) one-tail & 0,866887242 & \\
0,13 & 0,06 & t Critical one-tail & 2,20098516 & \\
0,07 & 0,1 & P(T<=t) two-tail & t Critical two-tail & \\
& &
\end{tabular}

Source: The author's calculations using the software package EXCEL

The results of the t-test are presented in Table 7. It clearly shows that, based on paired statistics, there is no statistically significant difference between those two groups of results (p-value is 0.867 ) whereby the starting hypothesis of the authors is proven.

In the considered case study, the proposed procedure enables for the decision-maker preferences to bethe basis for the pairwise comparison, and they are used as efficiency measures of the criteria in the realization of the highest possible amount of investment per capita in the individual municipalities. Thus generated weights can also serve as the basis for testing the relevance of the criteria. In fact, if there are any criteria that show very low efficiency, their relevance in the model should be reexamined. Such a procedure achieves a substantial improvement in the model for the BFC process, both in terms of determining the weights, and with regard to the continuity of the testing criteria relevance.

Finally, the results of this paper can be a good starting point for further research. The authors show that the proposed procedure exists as applicable, but the paper does not consider the degree of quality with 
relation to other known procedures. Namely, to make such an analysis, it would be necessary to conduct a research with more than one case study, and more than one method of integration for comparison.

\section{REFERENCES}

Alonso, J. A., \& Lamata, T. (2006). Consistency In The Analytic Hierarchy Process: A New Approach. International Journal of Uncertainty, Fuzziness and KnowledgeBased Systems, 14(4), 445-459.

Banker, R. D., Charnes, A., \& Cooper, W. W. (1984). Some Models for Estimating Technical and Scale Inefficiencies in Data Envelopment Analysis. Management Sciences, 30, 1078-1092.

Bfcsee (2014). http://www.bfcsee.org/Certification_criteria

Bozoki, S. (2008). Solution of the Least Squares Method problem of pairwise comparison matrices.European Journal of Operational Research (EJOR), 16, 345-358.

Certification program business-friendly municipality (2012). http://www.naled serbia.org/documents/download/Certification_brochure_2012.pdf

Charnes, A., Cooper, W. W., \& Rhodes, E. (1978). Measuring the efficiency of decision making units. European Journal of Operational Research, 2(6), 429-444

Chen H. J., \& Bai, J. F. (2013). Weight Determination Method Based on Principal Component Analysis Coking. Advanced Materials Research, Vol. (712-715), 2469-2473.

Cooper, W.W., Seiford L.M., \& Tone, K. (2000). Data envelopment analysis: a comprehensive text with models, applications, references and DEA-solver software. Boston:Kluwer Academic Publishers.

Cooper, W., Seiford, L.M., \& Tone, K. (2006). Introduction to Data Envelopment Analysis and its Uses with DEA-Solver Software and References. New York: Springer.

Doyle, J., \& Green, R. (1993). Data envelopment analysis and multiple criteria decisionmaking. Omega, 21(6), 713-715.

FormanE.H. (1990). Random indices for Incomplete Pairwise Comparison Matrices, European Journal of Operational Research, 48, 153-155.

Ginevičius R., \& Podvezko, V. (2004). Objective and subjective approaches to determining the criterion weight in multicriteria models. Proceedings of International Conference RelStat' 04, Part 1, Riga, Latvia, p. 133-137.

Hwang, C. L., Yoon, K. (1981).Multiple Attribute Decision Making: Methods and Applications. Berlin: Springer.

Jahanshahloo, G.R., Zohrehbandian M., \& Abbasian-Naghneh, S. (2011). Using Interactive Multiobjective Methods to Solve Multiple Attribute Decision Making Problems.Australian Journal of Basic and Applied Sciences, 5(9), 298-308.

Leskinen, P. (2000). Measurement scales and scale independence in the Analytic Hierarchy Process. Journal of Multi-Criteria Decision Analysis, 9, 163-174.

Li, D.F., Chen, G.H., \& Huang, Z.G. (2013). Linear programming method for multiattribute group decision making using IF sets. Information Sciences, v180 i9, 1591-1609.

Liu, F.H.F., \& Hai, H.L. (2005). The voting analytic hierarchy process method for selecting supplier. International Journal of Production Economics, 97(3), 308-317. 
Liu, Chun-Chu. (2003). Simulating Weights Restrictions in Data Envelopment Analysis by the Subjective and Objective Integrated Approach. Web Journal of Chinese Management Review, 6(1), 68-78.

Ma, J., Fan, Z.P., \& Huang, L.H. (1999). A subjective and objective integrated approach to determine attribute weights. European Journal of Operational Research, 112, 397-404.

Ma, J., \& Zhang, Q. (1991). 9/9-9/1 scale method of the AHP. Proceedings of 2nd Int. Symposium on the AHP,Pittsburgh, USA, Vol. 1, p. 197-202.

Naled-serbia (2012). http://www.naled-serbia.org

Podinovski, V. V. (1999). Side effects of absolute weight bounds in DEA models. EJOR, 115, 583-595.

Radukic, S., Stankovic J., \& Popovic, Z. (2012). The Goals and Limitations of Multicriteria Models of Environmental Protection, Economic Themes, 4, 669-681.

Ranđelović, D., Ranđelović, M., Savić, G., \& Makajić-Nikolić, D. (2013). Aggregation Statistics and the Methods of Operational Research for Weighting Criteria in Multiple Criteria Decision Making. Metalurgia International, Vol XVIII(4), 111-119.

Ramanathan, R. (2006). Data envelopment analysis for weight derivation and aggregation in the analytic hierarchy process.Computers and Operations Research, 33, $1289-1307$.

Saaty, T. L. (1994). Fundamentals of Decision Making.Pittsburgh:RWS Publications.

Saaty, T. L. (1977). A scaling method for priorities in hierarchical structures.Journal of Mathematical Psychology, 15, 234-281.

Saaty, T.L. (1980). Multi-criteria decision making: the Analytic Hierarchy Process. New York: McGraw-Hill.

Savić, G., Makajić-Nikolić, D., Ranđelović, D.,\&Ranđelović, M. (2013). Study Program Selection by Aggregated DEA-AHP Measure. Metalurgia International, 18 (1), 169-174.

Seifert, L.M., Zhu, J. (1998). Identifying excesses and deficits in Chinese industrial productivity (1953-1990): a weighted data envelopment analysis approach. Omega, 26(2), 279-396.

Shang, J., \& Sueyoshi, T. (1995). A unified framework for the selection of a flexible manufacturing system. European Journal of Operational Research, 85(2), 297-315.

Shannon C. E.,\& Weaver, W. (1947). The Mathematical Theory of Communication Urbana. Illionois: The University of Illinois Presss.

Sinuany-Stern, Z., Abraham, M., \& Yossi, H. (2000). An AHP/DEA methodology for ranking decision making units.International Trans. in Operational Research, 7(2), 109-124.

Statistical Office of the Republic of Serbia, Municipalities and Regions in the Republic of Serbia in 2012 (2012). http://webrzs.stat.gov.rs/WebSite/repository/documents/ 00/00/54/08/OpstinskigodisnjakRepublike_Srbije_2011.zip

Wang, Y.M., Liu, Y., \& Elhag, T.M.S. (2008). An integrated AHP-DEA methodology for bridge risk Assessment. Computers \& Industrial Engineering, 54 (3), 513-525.

Yang,T., \& Chunwei, K. A. (2003). A hierarchical AHP/DEA methodology for the facilities layout design problem. European Journal of Operational Research, 147(1), 128-136.

Zionts, S. (1992) Some thoughts on research in multiple criteria decision making. Computers and Operations Research, 19(7), 567-637. 


\title{
ЈЕДНА ИНТЕГРИСАНА ДЕА/АХП МЕТОДОЛОГИЈА ЗА ОДРЕЪИВАЫЕ ЗНАЧАЈА КРИТЕРИЈУМА У ПРОЦЕСУ ПОСЛОВНО-ПРИЈАТЕЉСКЕ ЦЕРТИФИКАЦИЈЕ НА ЛОКАЛНОМ НИВОУ
}

\author{
Милан Ранђеловић ${ }^{1}$, Гордана Савић ${ }^{2}$, \\ Бобан Стојановић ${ }^{3}$, Драган Ранђеловић ${ }^{4}$ \\ ${ }^{1}$ Научно-технолошки парк Ниш, Ниш, Србија \\ ${ }^{2}$ Универзитет у Београду, Факултет организационих наука, Београд, Србија \\ ${ }^{3}$ Универзитет у Нишу, Економски факултет, Ниш, Србија \\ ${ }^{4}$ Криминалистичко-полицијски универзитет Београд, Србија
}

\section{Резиме}

У процесу пословно-пријатељске цертификације, на локалном нивоу нужне, како би локалне самоуправе могле да планирају и управљају политиком обезбеђивања конкурентних услова за стимулацију улагања и унапређење свог пословног амбијента, кључни проблем јесте утврдити важност критеријума, за шта су на располагању различити вишекритеријумски методи одлучивања. Већина коришћених класификација те методе дели на две групе: субјективне и објективне. У овом раду представљен је један метод њихове интеграције коришћењем метода аналитичке хијерархије (АХП), као метода субјективне анализе, и метода анализе података (ДЕА), као објективног приступа са идејом увођења објективности у процес прорачуна важности критеријума са АХП методом, узимајући у обзир тежине добијене помоћу процене ефикасности ДЕА методом, а после увођења субјективитета у ДЕА експертско мишљење.

У разматраном случају, предложени поступак омогућава да се за доносиоце одлука као основа за упоредно упоређивање користе мерила ефикасности критеријума у остваривању највише могућег износа улагања по глави становника у дотичној општини. Тако генерисане тежине могу такође послужити као основа за тестирање релевантности критеријума. У ствари, ако постоје критеријуми који показују веома ниску ефикасност, њихову релевантност у моделу треба поново испитати. Овакав поступак постиже значајно побољшање у моделу БФЦ процеса - како у погледу одређивања тежине тако и у погледу континуитета критеријума испитивања.

Једноставним речима, предложени интегрисани поступак, у почетку, извршава субјективизацију објективне ДЕА методе користећи субјективну процену стручњака за коефицијенте тежине у моделу. Даље, процес је обрнут, тј. извршена је објективизација субјективног АХП приступа кроз примену тежина које су у претходном кораку одређене користећи ДЕА методологију. 